\title{
UJI AKTIVITAS ANTIBAKTERI EKSTRAK KASAR ETANOL, KLOROFORM DAN N-HEKSANA ALGA COKLAT Sargassum vulgare ASAL PANTAI KAPONG PAMEKASAN TERHADAP BAKTERI Staphilococcus aureus dan Eschericia coli
}

\author{
Alfiyaturohmah, Rachmawati Ningsih., Eriyanto Yusnawan
}

Jurusan Kimia, Fakultas Sains dan Teknologi, UIN Maulana Malik Ibrahim Malang

\begin{abstract}
The antibacterial activity of ethanol, chloroform and $n$-hexane crude extract of brown algae $S$. vulgare from Kapong beach Pamekasan has been conducted against $S$. aureus and E. coli. The purpose of this research was to know the crude solvent extract showing antibacterial activities against $S$. aureus and E. coli and to identifity active compound groups content.

The extraction of brown algae was performed by maseration ethanol, chloroform and $n$-hexane solvent. The crude extract were assayed an actibacterial activity by disk diffusion methode. The extract showing the best antibacterial activities were tested phytochemicals assay and TLC to identifity active compound groups.

This result showed that chloroform crude extract of brown algae inhibited $S$. aureus in concentration of 1 $\%$ and $E$. coli in concentration of $5 \%$. Phytochemical assay showed that chloroform crude extract was containing flavonoids and steroid groups. For the separation using TLC chloroform-methanol (99:1) yielded 9 spots with Rf 0,017-0,46 while chloroform-methanol (9:1) was generated 7 spots with Rf 0,17-0,91.
\end{abstract}

Keywords : Brown algae S. vulgare, antibacterial test, phytochemical test, TLC

\section{ABSTRAK}

Uji aktivitas antibakteri ekstrak kasar etanol, kloroform dan $n$-heksan alga coklat $S$. vulgare asal pantai Kapong Pamekasan dilakukan terhadap bakteri S. aureus dan E. coli. Tujuan penelitian untuk mengetahui ekstrak pelarut terbaik yang mempunyai aktivitas antibakteri serta mengidentifikasi golongan senyawa aktif yang terkandung dalam ekstrak yang berpotensi sebagai antibakteri.

Ekstraksi senyawa aktif alga coklat dilakukan dengan metode maserasi pelarut etanol, kloroform dan $n$ heksana. Ekstrak kasar diuji aktivitas antibakteri menggunakan metode difusi cakram. Senyawa aktif yang dikandung diuji fitokimia dan dipisahkan golongan senyawa menggunakan KLT.

Hasil penelitian menunjukkan ekstrak kloroform alga coklat memiliki aktivitas antibakteri terhadap bakteri S. aureus pada konsentrasi $1 \%$ dan terhadap E. coli pada konsentrasi 5\%. Hasil uji fitokimia terdeteksi golongan senyawa flavonoid dan steroid. Pemisahan menggunakan KLT eluen kloroform-metanol (99:1) menghasilkan 9 spot dengan nilai Rf 0,017-0,46. Eluen kloroform-metanol (9:1) menghasilkan 7 spot dengan nilai Rf $0,17-0,91$.

Kata Kunci: Alga coklat S. vulgare, aktivitas antibakteri, Uji fitokimia, KLT

\section{PENDAHULUAN}

Indonesia merupakan negara kepulauan terbesar di dunia. Secara fisik, Indonesia mempunyai panjang garis pantai mencapai $81.000 \mathrm{Km}^{2}$ dengan jumlah pulau mencapai lebih dari 17.500 pulau. Luas daratan 1,9 juta $\mathrm{Km}^{2}$ sementara luas perairan 3,1 juta $\mathrm{Km}^{2}$ (Yudanto, 2010). Perbandingan luas wilayah lautan dan daratan berbanding 3:1, sehingga hampir $70 \%$ wilayah Indonesia terdiri atas lautan yang memiliki sumber daya alam laut yang melimpah dan beragam baik hayati maupun non hayati.
Allah telah menciptakan laut dengan berbagai biota laut yang ada di dalamnya. Manusia bisa mengambil dan memanfaatkannya untuk kelangsungan hidupnya agar mereka senantiasa bersyukur atas nikmat-Nya yang tersirat dalam surat an Nahl ayat 14, yang artinya.

"Dan Dia-lah, Allah yang menundukkan lautan (untukmu), agar kamu dapat memakan daripadanya daging yang segar (ikan), dan kamu mengeluarkan dari lautan itu perhiasan yang kamu pakai; dan kamu melihat bahtera berlayar padanya, 
dan supaya kamu mencari (keuntungan) dari karunia-Nya, dan supaya kamu bersyukur".

Salah satu karunia Allah SWT dan merupakan sumber daya hayati kelautan yang melimpah di Indonesia adalah alga. Kemelimpahan alga dapat diketahui dengan jumlah jenis alga yang sudah ditemukan. Di Indonesia, alga merah terdiri dari 452 jenis, alga 196 jenis dan alga coklat 134 jenis (Moosa, 1999).

Alga coklat mengandung senyawa bioaktif seperti Fucoxantin (Ibanez dkk., 2012), steroid (Ayyad dkk., 2003), phlorotannin (Koivikko, 2008; Ibanez dkk., 2012), flavonoid (Cox dkk., 2010) dan saponin (Anandhan dkk., 2011). Senyawa bioaktif yang dikandung alga merupakan potensi yang sangat bermanfaat bagi pengembangan bidang farmasi, misalnya sebagai senyawa obat seperti antibakteri (Bactiar, 2007).

Senyawa antibakteri merupakan suatu senyawa yang dapat mencegah terjadinya pertumbuhan dan reproduksi bakteri. Salah satu cara untuk mengetahui aktivitas antibakteri menggunakan metode difusi cakram dengan pengamatan zona hambat. Cristobel dkk. (2011) melakukan uji aktivitas antibakteri alga coklat S.wightii, Padina tetrstromatica dan Dictyota dichotoma dengan konsentrasi 0,1\%, $1 \%$ dan $10 \%$ terhadap bakteri $S$. aureus, Streptococcus sp., Bacillus subtilis, Micrococcus luteus, Proteus mirabilis, Pseudomonas aeruginosa, Klebsiella pneumoniae dan E. coli. Ekstrak etanol dan kloroform alga coklat jenis $P$. gymnospora dan $S$. tenerrium berturutturut dihasilkan zona hambat sebesar 11,3 $\mathrm{mm}$ dan $13,7 \mathrm{~mm}$ pada E. coli dan 12,0 $\mathrm{mm}$ serta $20,3 \mathrm{~mm}$ pada $S$. aureus (Mannifannan dkk., 2011). Ekstrak nhekana S. cristaefolium menghasilkan zona hambat $8,2 \mathrm{~mm}$ pada E. coli (Rohmah dkk., 2011).

Alga coklat jenis $S$. vulgare merupakan alga coklat yang satu marga dengan $T$. conoides, $P$. gymnospora, $S$. tenerrium dan lain-lain. Alga-alga tersebut sudah diteliti daya aktivitas antibakterinya terhadap S.aureus dan E.coli yang bersifat patogen, sehingga dapat diduga bahwa $S$. vulgare juga mempunyai potensi sebagai antibakteri.

Menurut Asmad (2012), penduduk dan nelayan pantai Kapong Kabupaten Pamekasan, keberadaan S. vulgare di pantai tersebut melimpah. Kemelimpahan alga ini dibiarkan begitu saja kecuali dijual hanya jika ada yang pesan. Berdasarkan informasi tersebut alga coklat perlu ditingkatkan potensinya dengan cara diteliti guna mengetahui kandungan senyawa aktif khususnya yang berpotensi sebagai senyawa obat.

Berdasarkan latar belakang di atas, perlu dilakukan suatu penelitian untuk mendapatkan dasar teoritis dan bukti-bukti ilmiah kepada masyarakat tentang penggunaan alga coklat sebagai senyawa obat khususnya antibakteri. Pada penelitian ini akan dilakukan uji aktivitas ekstrak kasar etanol, kloroform dan $n$ - heksana alga coklat sebagai senyawa aktif antibakteri terhadap bakteri $\quad$ S. aureus dan E. coli.

\section{PELAKSANAAN PENELITIAN}

Penelitian ini dilaksanakan di Laboratorium UIN Maulana Malik Ibrahim Malang pada bulan Juni 2012 sampai September 2012.

\section{Alat dan Bahan}

Peralatan yang digunakan antara lain: timbangan analitik, Salinometer Atago $P A L-06 S$, oven, desikator, seperangkat alat gelas, shaker, kertas saring, corong Buchner, rotary evaporator, pipet, botol vial, cawan petri, Laminar Air Flow, inkubator, mikropipet, kawat ose, bunsen, mistar, plastik tahan panas, alumunium foil, karet, autoklaf, tabung reaksi, rak tabung, plat tetes, pipa kapiler dan lampu UV.

Bahan utama yang digunakan alga coklat $S$. vulgare, aquades, etanol, kloroform, $n$-heksana, asam sulfat, reagen Dragendorf, reagen Mayer, reagen 
Liberman-Burchard, serbuk magnesium, asam klorida, besi (III) klorida, asam asetat anhidrat, larutan Tween, kertas saring, ampicilin, streptomicin, alkohol $80 \%$, plat KLT $\mathrm{GF}_{254}$, kertas Watman, kapas, wrap, Nutrien Agar (NA) (Criterion America), Nutrirnt Broth (NB) (Criterion America) dan biakan murni bakteri $S$. aureus dan $E$. coli.

\section{PROSEDUR PENELITIAN \\ Preparasi Sampel}

Alga dicuci dengan air dan dibilas berulang-ulang sampai bersih. Dikeringanginkan selama 7 hari (Reskika, 2010). Dihaluskan dengan blender dan diayak dengan ayakan ukuran 60-100 mesh.

\section{Analisa Kadar Air}

Sebanyak 5 gram serbuk sampel pada cawan konstan dipanaskan dalam oven pada suhu $100-105^{\circ} \mathrm{C}$ sekitar 15 menit. Cawan disimpan dalam desikator sekitar 10 menit selanjutnya ditimbang. Dilakukan pengulangan sampai deperoleh berat konstan. Rumus kadar air (AOAC 1984):

$$
\% \text { Kadar air : }{ }^{\frac{b-c}{b-a}} \times 100 \%
$$

Ket: $\mathrm{a}=$ berat konstan cawan kosong

$\mathrm{b}=\mathrm{a}+$ sampel sebelum kering

$\mathrm{c}=\mathrm{a}+$ sampel kering

\section{Analisa Kadar Garam}

Sebanyak 5 gram serbuk alga coklat ditimbang kemudian dilarutkan aquades panas $10 \mathrm{~mL}$, diaduk menggunakan magnetic stirrer dan ditunggu \pm 30 menit sehingga semua garam $(\mathrm{NaCl})$ larut (Sudarmadji, dkk., 2007). Ekstrak disaring dengan corong Buchner setelah itu uji kadar garam menggunakan Salinometer Atago PAL-06S.

\section{Ekstraksi}

Maserasi sebanyak 100 gram serbuk sampel kedalam masing-masing $1000 \mathrm{~mL}$ pelarut etanol, kloroform, dan $n$-heksana selama 24 jam pada suhu ruang. Shaker 3 jam dan disaring menggunakan corong Buchner. Filtrat dipeketkan dengan rotary evaporator.

\section{Pengujian Antibakteri}

Pengujian dengan metode difusi cakram. Kertas cakram $5 \mathrm{~mm}$ diresapkan pada masing-masing ekstrak dengan konsentrasi $10 \%, 7,5 \%, 5 \%, 2,5 \%, 1 \%$ dan $0,5 \%$. Pelarut ekstrak digunakan akuades dengan sedikit tween. Kertas cakram yang mengandung ekstrak diletakkan diatas permukaan media agar padat yang telah dihomogenkan dengan $50 \mu \mathrm{L}$ bakteri biakan aktif (OD 0,3). Diinkubasi selama 24 jam pada suhu $37^{0} \mathrm{C}$.

\section{Uji Fitokimia}

Ekstrak pelarut yang positif menunjukkan aktivitas antibakteri diuji fitokimia dengan uji reagen.

\section{Uji Flavonoid}

Sebanyak 0,5 gram ekstrak alga coklat dimasukkan dalam tabung reaksi kemudian dilarutkan dalam 1-2 $\mathrm{mL}$ metanol $50 \%$. Setelah itu ditambah logam $\mathrm{Mg}$ dan 4-5 tetes $\mathrm{HCl}$ pekat. Larutan berwarna merah atau jingga yang terbentuk menunjukkan adanya flavonoid (Hayati, 2010).

\section{Uji Tanin denganF $\mathrm{eCl}_{3}$}

Sebanyak $1 \mathrm{~mL}$ ekstrak alga coklat ditambahkan dengan 2-3 tetes larutan $\mathrm{FeCl}_{3} 1 \%$. Jika dihasilkan warna hijau kehitaman atau biru tua pada larutan maka menunjukkan adanya tanin (Hayati, 2010).

\section{Uji Tanin dengan Larutan Gelatin}

Sebanyak $1 \mathrm{~mL}$ ekstrak alga coklat dimasukkan dalam tabung reaksi ditambah dengan larutan gelatin. Jika terbentuk endapan putih, menunjukkan adanya tanin (Hayati, 2010).

\section{Uji Alkaloid}

Ekstrak alga coklat sebanyak $3 \mathrm{~mL}$ dimasukkan dalam tabung reaksi dan ditambah $1 \mathrm{~mL} \mathrm{HCl} 1 \%$. Larutan dibagi dalam dua tabung. Tabung 1 ditambah 2-3 tetes reagen Dragendroff, tabung II ditambah 2-3 tetes reagen Mayer. Jika tabung 1 terbentuk endapan jingga dan tabung II terbentuk endapan kekuningkuningan menunjukkan adanya alkaloid (Hayati, 2010). 


\section{Uji Saponin}

Ekstrak alga coklat dimasukkan dalam tabung reaksi ditambah air (1:1) sambil dikocok selama 1 menit, apabila menimbulkan busa ditambahakan $\mathrm{HCl} 1 \mathrm{~N}$ sebanyak 1-2 tetes, busa yang terbentuk dapat bertahan selama 10 menit dengan ketinggian 1-3 cm, maka ekstrak positif mengandung saponin (Hayati, 2010).

\section{Uji Steroid/ Triterpenoid}

Ekstrak alga coklat sebanyak $1 \mathrm{~mL}$ dimasukkan dalam tabung reaksi, dilarutkan dalam $0,5 \mathrm{~mL}$ kloroform lalu ditambah dengan $0,5 \mathrm{~mL}$ asam asetat anhidrat. Campuran ini selanjutnya ditambah dengan 1-2 $\mathrm{mL} \mathrm{H}_{2} \mathrm{SO}_{4}$ pekat melalui dinding tabung. Jika hasil yang diperoleh berupa cincin kecoklatan atau violet pada perbatasan dua pelarut menunjukkan adanya triterpenoid, sedangkan jika terbentuk warna hijau kebiruan menunjukkan adanya steroid (Hayati, 2010).

\section{Pemisahan Senyawa Aktif}

Ekstrak pelarut yang positif uji fitokimia dipisahkan golongan senyawanya menggunakan KLT Silika $\mathrm{GF}_{254}$.

\section{Analisa data}

Data aktivitas antibakteri dianalisis ragam uji ANOVA satu arah untuk menguji adanya pengaruh atau perbedaan antar perlakuan variasi konsentrasi ekstrak alga coklat terhadap pertumbuhan bakteri. Apabila terdapat pengaruh atau perbedaan antar perlakuan, diuji lanjut uji Beda Nyata Terkecil (BNT) dengan tingkat signifikansi 5\% untuk mengetahui perlakuan yang berpengaruh atau berbeda nyata di antara perlakuan yang lain.

\section{HASIL DAN PEMBAHASAN Preparasi Sampel}

Pencucian sampel dilakukan agar kotoran pada alga hilang. Pengeringan dengan proses kering-angin untuk menghindari rusaknya senyawa aktif pada sampel yang tidak tahan terhadap panas. Pengeringan untuk mengurangi kadar air, mencegah terjadinya reaksi enzimatis dan tumbuhnya jamur sehingga dapat disimpan dalam jangka waktu yang lebih lama. Hasil dari pengeringan berupa alga kering dan berwarna hitam dengan rendemen $13,80 \%$. Besarnya kadar air yang diperoleh hampir sama dengan $S$. prismatikum proses keringangin yang diteliti oleh Reskika (2011) yang besarnya $12,36 \%$. Pada proses pengeringan yang sama, penelitian Putri (2010) menginformasikan bahwa kadar air Sargassum sp. sebesar 14,90\%. Perbedaan kadar air dapat disebabkan oleh perbedaan tempat dan waktu pengeringan.

Penghalusan untuk memperluas permukaan sampel, sehingga kontak antara sampel dengan pelarut semakin besar pada saat ekstraksi. Serbuk sampel yang dihasilkan berwarna coklat kehitaman dan berbau menyengat (gurih).

\section{Analisa Kadar Air}

Hasil kadar air serbuk alga coklat melalui proses pemanasan menggunaan oven sebesar $11,80 \%$, dengan proses yang sama kadar yang dihasilkan hampir sama dengan kadar air Sargassum sp yang diteliti oleh Putri (2010) yang besarnya $12,32 \%$. Kadar air mempunyai peranan penting dalam menentukan daya awet suatu bahan (Buckle, 2006). Menurut Winarno (2004), apabila kandungan air bahan berkisar 12-25 \% kira-kira setara dengan $\mathrm{a}_{w} 0,8$. Aktivitas air (water activity $=\mathrm{a}_{w}$ ) merupakan jumlah air di dalam bahan yang tersedia untuk pertumbuhan mikroorganisme. Penghambatan mikroba secara total akan terjadi pada $\mathrm{a}_{\mathrm{w}}$ bahan < 0,6 setara dengan kadar air $<7 \%$. Kadar air S. vulgare masih tergolong tinggi karena $\%$ kadar air lebih besar dari 7\% sehingga pertumbuhan mikroba cenderung dapat terjadi, untuk mengantisipasi hal tersebut penyimpanan sampel serbuk kering pada lemari pendingin.

\section{Analisa Kadar Garam}

Hasil kadar garam yang diperoleh sebesar 0,74\%. Menurut Buckle dkk. (2010), garam berperan sebagai penghambat selektif pada proteolitik (mikroorganisme pembusuk) dan pembentukan spora meskipun dengan kadar rendah $6 \%$. S. aureus akan dihambat 
pertumbuhannya pada konsentrasi garam 15-20\% sedangkan E. coli pada $13 \%$. Kadar garam alga coklat tergolong sangat rendah sehingga pada saat proses uji aktivitas antibakteri cenderung tidak memiliki pengaruh penghambatan bakteri uji. Terhambatnya pertumbuhan bakteri uji cenderung murni dari senyawa aktif yang terkandung dalam ekstrak alga coklat.

\section{Ekstraksi}

Presentase ekstrak kasar alga coklat dapat dilihat pada Tabel 1.

Tabel 1 Hasil presentase ekstrak kasar alga coklat

\begin{tabular}{lcc}
\hline Ekstrak & $\begin{array}{c}\text { Ekstrak } \\
\text { kasar }(\mathbf{g})\end{array}$ & $\begin{array}{c}\text { Ekstrak } \\
\text { kasar }(\%)\end{array}$ \\
\hline Etanol & 1,76 & 1,76 \\
Kloroform & 1,60 & 1,60 \\
$n$-heksana & 0,50 & 0,50 \\
\hline
\end{tabular}

\section{Uji Aktivitas Antibakteri}

Pengujian aktivitas antibakteri ekstrak kasar alga coklat terhadap bakteri $S$. aureus dan E. coli dengan 3 kali pengulangan dapat dilihat pada Tabel 2 dan Tabel 3.

Tabel 2 Aktivitas antibakteri ekstrak kasar alga coklat terhadap bakteri $S$. aureus

\begin{tabular}{|c|c|c|c|}
\hline \multirow[t]{2}{*}{ Konsentrasi } & \multicolumn{3}{|c|}{ Zona hambat (mm) } \\
\hline & $\begin{array}{c}\text { Ekstrak } \\
\text { etanol }\end{array}$ & $\begin{array}{c}\text { Ekstrak } \\
\text { klorofor } \\
\text { m }\end{array}$ & $\begin{array}{c}\text { Ekstrak } \\
n \text {-heksana }\end{array}$ \\
\hline $10 \%$ & - & - & - \\
\hline $7,5 \%$ & - & - & - \\
\hline $5 \%$ & - & $1,0000^{\mathrm{c}}$ & - \\
\hline $2,5 \%$ & - & $1,6667^{\mathrm{bc}}$ & - \\
\hline $1 \%$ & - & $1,8883^{b}$ & - \\
\hline $0,5 \%$ & - & $\underset{\text { cd }}{0,5000}$ & - \\
\hline $\begin{array}{l}\text { Ampisilin } \quad(0,4 \\
\mathrm{mg} / \mathrm{mL})\end{array}$ & 13,0000 & $\underset{\mathrm{a}}{13,0000}$ & 13,0000 \\
\hline $\begin{array}{l}\text { Kontrol } \\
\text { aquades }\end{array}$ & - & - & - \\
\hline $\begin{array}{l}\text { Kontrol pelarut } \\
\text { organik }\end{array}$ & - & - & - \\
\hline TPC (CFU/mL) & $1,8 \times 10^{8}$ & $2,5 \times 10^{8}$ & $2,5 \times 10^{8}$ \\
\hline
\end{tabular}

Ekstrak kloroform alga coklat menunjukkan aktivitas antibakteri sedangkan ekstrak etanol dan $n$-heksana sebaliknya, hal tersebut dimungkinkan karena senyawa aktif antibakteri cenderung terdistrubusi pada pelarut semipolar. Aktivitas antibakteri pada ekstrak semipolar juga ditunjukkan pada penelitian Borbon dkk. (2012), yakni mengekstrak alga coklat $S$. policeratum dan Dictyota mertensii dengan pelarut etanol (polar) dan aseton (semipolar). Ekstrak aseton kedua alga menunjukkan aktivitas antibakteri terhadap E.coli sedangkan ekstrak etanol sebaliknya. Ekstrak $n$-heksana alga coklat Turbinaria conoides tidak menunjukkan aktivitas antibakteri pada $S$. aureus (Shanmugam dkk., 2010) kemudian ekstrak S. abbottiae dan S. bataananse pada E. coli (Shidarta dkk., 2008).

Tabel 3 Aktivitas antibakteri ekstrak kasar alga coklat terhadap bakteri E. coli

\begin{tabular}{|c|c|c|c|}
\hline \multirow[t]{2}{*}{ Konsentrasi } & \multicolumn{3}{|c|}{ Zona hambat (mm) } \\
\hline & $\begin{array}{c}\text { Ekstra } \\
\mathbf{k} \\
\text { etanol }\end{array}$ & $\begin{array}{c}\text { Ekstrak } \\
\text { kloroform }\end{array}$ & $\begin{array}{c}\text { Ekstrak } \\
n- \\
\text { heksana }\end{array}$ \\
\hline $10 \%$ & - & $1,6667^{b}$ & - \\
\hline $7,5 \%$ & - & $0,6667^{b c}$ & - \\
\hline $5 \%$ & - & $0,6667^{\mathrm{bc}}$ & - \\
\hline $2,5 \%$ & - & - & - \\
\hline $1 \%$ & - & - & - \\
\hline $0,5 \%$ & - & - & - \\
\hline $\begin{array}{l}\text { Streptomosin } \\
(0,625 \\
\text { mg/mL) }\end{array}$ & 22,1667 & $22,1667^{a}$ & 22,16667 \\
\hline $\begin{array}{l}\text { Kontrol } \\
\text { aquades }\end{array}$ & - & - & - \\
\hline $\begin{array}{l}\text { Kontrol } \\
\text { pelarut } \\
\text { organik }\end{array}$ & - & - & - \\
\hline $\begin{array}{l}\text { TPC } \\
(\mathrm{CFU} / \mathrm{mL})\end{array}$ & $2,7 \times 10^{8}$ & $4,2 \times 10^{8}$ & $4,2 \times 10^{8}$ \\
\hline
\end{tabular}

Ekstrak kasar kloroform alga coklat menunjukkan aktivitas antibakteri yang cenderung lemah dibandingkan senyawa obat komersil (ampisilin dan streptomisin), karena zona hambat yang dihasilkan $<5$ $\mathrm{mm}$. Efektivitas antibakteri yang lebih baik ditunjukkan pada konsentrasi $1 \%$ terhadap $S$. aureus sedangkan terhadap E. coli pada konsentrasi $5 \%$. Penentuan konsentrasi terbaik pertama-tama melihat perlakuan konsentrasi yang nilai rata-ratanya 
tertinggi. Setelah itu melihat apakah nilai tertinggi tersebut diikuti oleh huruf yang sama atau tidak. Jika diikuti huruf yang sama, dibandingkan antara konsentrasi dosis tinggi dan dosis rendah. Perlakuan dosis rendah lebih baik dari pada dosis tinggi jika direkomendasikan sebagai senyawa obat, hal tersebut untuk menghindari resistensi bakteri akibat pemberian antibakteri secara berlebihan.

Pada umumnya semakin besar konsentrasi senyawa obat antibakteri menghasilkan zona hambat yang semakin besar pula. Konsentrasi ekstrak kloroform alga coklat terhadap bakteri $S$. aureus menunjukkan sebaliknya. Hal yang sama terjadi pada penelitian Cristobel dkk. (2011) yang menguji ekstrak kasar $S$. wightii, ulva fasciata (alga hijau) dan Gracilaria corticata (alga merah) terhadap bakteri Gram positif (Micrococcus luteus) dengan konsentrasi $0,1 \% ; 1 \% ; 10 \% 50 \%$ dan $100 \%$. Pada konsentrasi $50 \%$ dan $100 \%$ tidak menghasilkan zona hambat.

\section{Uji Fitokimia}

Flavonoid dan steroid dapat berfungsi sebagai antibakteri karena dapat merusak dinding sel bakteri (Abad dkk., 2011), mengganggu permeabilitas membran sel, proses sintesis protein dan DNA (Volk and Wheller, 1993). Aktivitas antibakteri senyawa flavonoid terdapat pada gugus hidroksil bebas pada cincin A, $\mathrm{C}_{5}$ dan $\mathrm{C}_{7}$ (Saleem dkk., 2010). Selain itu pada gugus hidroksil pada cincin B, 3', 4',5'trihydroxyflavonoids (Bylka dkk., 2010).

Sifat antibakteri senyawa steroid terdapat pada gugus hidroksil 3- $\beta \mathrm{OH}$ (Saleem dkk., 2010).

\section{Pemisahan Senyawa Aktif dengan KLT}

Pemisahan golongan senyawa aktif flavonoid menggunakan larutan pengembang campuran kloroform-metanol (9: 1) yang merujuk penelitian Marimuthu dkk. (2012), yakni memisahkan senyawa aktif alga $S$. wightii yang mengandung senyawa fenol dan flavonoid. Hasil pemisahan golongan senyawa aktif flavonoid alga coklat pada Tabel 5.

Tabel 4 Hasil uji fitokimia ekstrak kasar kloroform alga coklat

\begin{tabular}{|c|c|c|c|}
\hline Uji & $\begin{array}{c}\text { Ekstrak } \\
\text { Alga } \\
\text { coklat }\end{array}$ & Warna & $\begin{array}{l}\text { Standar } \\
\text { warna }\end{array}$ \\
\hline Flavonoid & + & Hijau & $\begin{array}{l}\text { Merah/ } \\
\text { jingga/ } \\
\text { hijau }\end{array}$ \\
\hline \multicolumn{4}{|l|}{ Tanin } \\
\hline $\mathrm{FeCl}_{3}$ & - & $\begin{array}{l}\text { Coklat } \\
\text { kekuni } \\
\text { ngan }\end{array}$ & $\begin{array}{l}\text { Hijau } \\
\text { kehitaman/ } \\
\text { biru tua }\end{array}$ \\
\hline Gelatin & - & $\begin{array}{l}\text { Tidak } \\
\text { ada } \\
\text { endapa } \\
\text { n }\end{array}$ & $\begin{array}{l}\text { Endapan } \\
\text { putih }\end{array}$ \\
\hline \multicolumn{4}{|l|}{ Alkaloid } \\
\hline $\begin{array}{l}\text { Dragen } \\
\text { drof }\end{array}$ & - & $\begin{array}{l}\text { Endapa } \\
\mathrm{n} \\
\text { merah } \\
\text { muda }\end{array}$ & $\begin{array}{l}\text { Endapan } \\
\text { kekuning- } \\
\text { kuningan }\end{array}$ \\
\hline - Mayer & - & $\begin{array}{l}\text { Tidak } \\
\text { ada } \\
\text { endapa } \\
\text { n }\end{array}$ & $\begin{array}{l}\text { Endapan } \\
\text { jingga }\end{array}$ \\
\hline Saponin & - & $\begin{array}{l}\text { Tidak } \\
\text { terbent } \\
\text { uk busa }\end{array}$ & $\begin{array}{l}\text { Terbentuk } \\
\text { busa }\end{array}$ \\
\hline Steroid & + & $\begin{array}{l}\text { Biru } \\
\text { kehijau } \\
\text { an }\end{array}$ & $\begin{array}{l}\text { Biru } \\
\text { kehijauan }\end{array}$ \\
\hline $\begin{array}{l}\text { Triterpenoi } \\
\text { d }\end{array}$ & - & $\begin{array}{l}\text { Biru } \\
\text { kehijau } \\
\text { an }\end{array}$ & $\begin{array}{l}\text { Terbentuk } \\
\text { cincin } \\
\text { kecoklatan }\end{array}$ \\
\hline
\end{tabular}

Ket: Tanda + : terkandung senyawa

Tanda - :tidak terkandung senyawa

Warna noda pada nomor 7 dan 3 berwarna hijau biru dan kuning orange, setelah diuapi amoniak dan dilihat pada sinar $\mathrm{UV}_{336}$ berwarna jingga/ orange dan coklat hitam. perubahan warna yang dihasilkan cenderung sama seperti yang diteliti Fahri (2010) yang memisahkan senyawa flavonoid pada alga $S$. cristaefolium. Menurut Harborne (2006), senyawa flavonoid yang diuapi amonik menghasilkan warna biru, coklat muda/lemah, coklat tua, coklat hitam, merah muda, merah tua, jingga, kuning dan hijau kuning. Berdasarkan warna tersebut, ekstrak kloroform $S$. vulgare yang diduga 
mengandung flavonoid berwarna merah muda, coklat muda, biru dan jingga, yakni noda pada nomor 1, 3, 6 dan 7 .

Tabel 5 Hasil pemisahan golongan senyawa aktif flavonoid ekstrak kloroform alga coklat menggunakan KLT

\begin{tabular}{|c|c|c|c|c|}
\hline \multirow{3}{*}{$\begin{array}{l}\text { No } \\
\text { No } \\
\text { da }\end{array}$} & \multirow{3}{*}{$\begin{array}{l}\mathrm{Rf} \\
(\mathrm{cm})\end{array}$} & \multirow{3}{*}{$\begin{array}{l}\text { Warna } \\
\text { noda } \\
\text { tampak }\end{array}$} & \multicolumn{2}{|c|}{ Warna noda } \\
\hline & & & \multicolumn{2}{|c|}{ dibawah sinar $U V_{366}$} \\
\hline & & & $\begin{array}{c}\text { Sebelum } \\
\text { diuapi } \\
\text { amoniak }\end{array}$ & $\begin{array}{c}\text { Setelah } \\
\text { diuapi } \\
\text { amoniak }\end{array}$ \\
\hline 1 & 0,17 & $\begin{array}{l}\text { Kuning } \\
\text { pudar }\end{array}$ & Merah muda & Merah muda \\
\hline 2 & 0,41 & Kuning & Merah muda & Merah ungu \\
\hline 3 & 0,47 & $\begin{array}{l}\text { Orange } \\
\text { kuning }\end{array}$ & Coklat hitam & $\begin{array}{l}\text { Coklat } \\
\text { muda }\end{array}$ \\
\hline 4 & 0,53 & $\begin{array}{l}\text { Tak } \\
\text { berwarna }\end{array}$ & Merah muda & Merah ungu \\
\hline 5 & 0,80 & $\begin{array}{l}\text { Tak } \\
\text { berwarna }\end{array}$ & Merah muda & Biru \\
\hline 6 & 0,84 & $\begin{array}{l}\text { Tak } \\
\text { berwarna }\end{array}$ & Merah muda & Coklat \\
\hline 7 & 0,91 & Hijau biru & Jinga terang & Jingga \\
\hline
\end{tabular}

\section{KLT Senyawa Steroid}

Hasil pemisahan golongan senyawa aktif steroid alga coklat pada Tabel 6.

Pemisahan golongan senyawa aktif steroid menggunakan larutan pengembang campuran kloroform-metanol (99: 1) yang merujuk penelitian Kamenarska dkk. (2003), yang memisahkan senyawa steroid pada alga coklat Stilophora rhizodes, Punctaria latifolia dan P. plantaginea.

Pemisahan senyawa steroid menghasilkan 9 noda. Noda pada KLT terpisah berdasarkan tingkat kepolarannya. Noda dengan Rf terkecil yaitu 0,017 diduga cenderung bersifat polar dikarenakan noda tersebut lebih terdistribusi ke fase diam yang bersifat polar. Noda dengan $\mathrm{Rf}$ tertinggi 0,46 cenderung terdistribusi ke dalam fase gerak yang kepolarannya lebih kecil dibandingkan dengan fase diamnya.

Kristanti (2008) melaporkan bahwa senyawa steroid setelah disemprot pereaksi Liberman-Burchard pada plat KLT menghasilkan warna biru. Hasil KLT pemisahan senyawa steroid pada $S$. vulgare cenderung berwarna biru yang ditunjukkan pada noda nomor $1,2,3,4,5,6,7$ dan 8 .
Tabel 6 Hasil pemisahan golongan senyawa aktif steroid ekstrak kloroform alga coklat menggunakan KLT

\begin{tabular}{|c|c|c|c|c|c|}
\hline \multirow{3}{*}{$\begin{array}{l}\text { No } \\
\text { No } \\
\text { da }\end{array}$} & \multirow{3}{*}{$\begin{array}{l}\mathrm{Rf} \\
(\mathrm{cm})\end{array}$} & \multirow{3}{*}{$\begin{array}{c}\text { Warna } \\
\text { noda } \\
\text { tampak }\end{array}$} & \multicolumn{3}{|c|}{ Warna noda } \\
\hline & & & \multirow{2}{*}{$\begin{array}{c}\text { sinar UV } \\
256\end{array}$} & \multicolumn{2}{|c|}{ sinar $U V_{366}$} \\
\hline & & & & $\begin{array}{c}\text { - Pereaksi } \\
\text { L-B }\end{array}$ & $\begin{array}{c}+ \\
\text { Pereaksi } \\
\text { L-B }\end{array}$ \\
\hline 1 & 0,017 & $\begin{array}{l}\text { Kuning } \\
\text { muda }\end{array}$ & $\begin{array}{l}\text { Tak } \\
\text { berwarna }\end{array}$ & Merah & Biru \\
\hline 2 & 0,05 & $\begin{array}{l}\text { Kuning } \\
\text { muda }\end{array}$ & $\begin{array}{l}\text { Hijau } \\
\text { pudar }\end{array}$ & Merah & Biru \\
\hline 3 & 0,07 & Kuning & Hijau tua & $\begin{array}{l}\text { Hijau } \\
\text { kecoklatan }\end{array}$ & Biru \\
\hline 4 & 0,13 & $\begin{array}{l}\text { Tak } \\
\text { berwarn } \\
\text { a }\end{array}$ & $\begin{array}{l}\text { Tak } \\
\text { berwarna }\end{array}$ & $\begin{array}{l}\text { Merah } \\
\text { muda }\end{array}$ & Biru \\
\hline 5 & 0,21 & $\begin{array}{l}\text { Tak } \\
\text { berwarn } \\
\text { a }\end{array}$ & $\begin{array}{l}\text { Tak } \\
\text { berwarna }\end{array}$ & $\begin{array}{l}\text { Merah } \\
\text { muda }\end{array}$ & Biru \\
\hline 6 & 0,26 & $\begin{array}{l}\text { Tak } \\
\text { berwarn } \\
\text { a }\end{array}$ & $\begin{array}{l}\text { Tak } \\
\text { berwarna }\end{array}$ & $\begin{array}{l}\text { Merah } \\
\text { muda }\end{array}$ & Biru \\
\hline 7 & 0,30 & $\begin{array}{l}\text { Tak } \\
\text { berwarn } \\
\text { a }\end{array}$ & $\begin{array}{l}\text { Tak } \\
\text { berwarna }\end{array}$ & $\begin{array}{l}\text { Merah } \\
\text { muda }\end{array}$ & Biru \\
\hline 8 & 0,34 & $\begin{array}{l}\text { Takber } \\
\text { warna }\end{array}$ & $\begin{array}{l}\text { Tak } \\
\text { berwarna }\end{array}$ & $\begin{array}{l}\text { Merah } \\
\text { muda }\end{array}$ & Biru \\
\hline 9 & 0,46 & $\begin{array}{l}\text { Hijau } \\
\text { kebiruan }\end{array}$ & $\begin{array}{l}\text { Hijau } \\
\text { muda }\end{array}$ & $\begin{array}{l}\text { Merah } \\
\text { kecoklatan }\end{array}$ & $\begin{array}{l}\text { Biru - } \\
\text { merah }\end{array}$ \\
\hline
\end{tabular}

\section{PENUTUP \\ Kesimpulan}

Ekstrak alga coklat yang mempunyai aktivitas antibakteri terbaik adalah ekstrak kloroform pada konsentrasi $1 \%$ terhadap $S$. aureus dan 5\% terhadap E. coli. Golongan senyawa yang diduga pada ekstrak kloroform alga coklat adalah flavonoid dan steroid

\section{Saran}

Perlu menambah variasi konsentrasi untuk mengetahui efisiensi konsentrasi ekstrak. Ekstraksi menggunakan variasi pelarut organik lain perlu dilakukan untuk mengetahui aktivitas ekstrak pelarut sebagai antibakteri. Hidrolisis terhadap ekstrak pekat yang didapat juga perlu dilakukan terkait senyawa aktif yang berpotensi sebagai antibakteri dan identifikasi senyawa aktif menggunakan instrumen perlu dilakukan untuk mengetahui senyawa aktif yang dikandung alga coklat. 


\section{DAFTAR PUSTAKA}

Abad, M. J., Bedoya, L. M. and Bermejo P. 2011. Marine Compounds and their Antimicrobial Activities. Departamento de Farmacología, Facultad de Farmacia, Universidad Complutense, Avda. Complutense s/n, 28040, Madrid, Spain.

Anandhan, S. and Sorna K.H. Biorestraining potentials of marine macroalgae collected from Rameshwaram, Tamil nadu. Journal research Biology, An International Open Access Online Research Journal. 385-392. JRB. 2011 Vol 1. No 5

Asmad.2012.Wawancarakomunikasi.

Kelimpahan alga coklat jenis Sargassum vulgare di Pantai Kapong Kabupaten Pamekasan. 17 Maret 2012

Ayyad, S.N., Sowellim, S.Z.A., El-Hosini, M.S. and Abo-Atia, A. The Structural Determination of a New Steroidal Metabolite from the Brown Alga Sargassum asperifolium. Journal Department of Chemistry Dammietta Faculty of Science,Mansoura University. 0939D5075/2003/0500D0333.200 3

Bachtiar, E. 2007. Penelusuran Sumber Daya hayati (Alga) Sebagai Biotarget Industri. Universitas Padjadjaran. Fakultas Perikanan dan Ilmu Kelautan. Jatitagor

Bucle, K.A, Edwards, R.A, Fleet, G.H, Wootton, penerjemah: Adiono H.P. 2010. Ilmu Pangan. Jakarta: Universitas Indonesia Press

Bylka, W., Matlawska, I., Pilewski, N.A. Natural flavonoid as Antimicrobial Agents. Reviev ArticleDepartmentof Pharmacognosy,K.Marcinkowski University of Medicinal Sciences 10 Sieroca, 61-771 Poznan, Poland. JANA Vol. 7, No. 2, 2004
Borbon, H. et al., 2012. Antimicrobial Activity of Most Abundant Marine Macroalgae of the Caribbean Coast of Costa Rica. Journal of Asian Scientific Research, Vol. 2, No. 5, pp. 292299

Christobel, G.J., Lipton, A.P., Aishwarya, M.S., Sarika, A.R. and Udayakumar, A. Antibacterial activity of aqueous extract from selected macroalgae of southwest coast of India. Seaweed Res. Utiln., 33 (1\&2) : 67 - 75, 2011

Cox, S., Abu-Ghannam, N and Gupta, S. An assessment of the antioxidant and antimicrobial activity of six species of edible Irish seaweeds. International Food Research Journal 17: 205-220 (2010)

Fahri, M., Risjani, Y. dan Sasangka P. 2010. Isolation and Identification of Flavonoids Compounds and Toxicity Test Of Methanolextract From Brown Algae (Sargassum cristaefolium). Malang: UB

Hayati, E. K dan Halimah, N. Phytochemical Test and Brine Shrimp Lethally Test Against Artemia salina Leach Antinganting (Achalypha indica Linn.) Plant Ekstract. ALCHEMY Vol. No. 2Maret 2010, hal 53-103

Ibañez, E., Herrero, M., Mendiola, J.A. and Castro-Puyana, M. Chapter 2 Extraction and Characterization of Bioactive Compounds with Health Benefi ts from Marine Resources: Macro and Micro Algae, Cyanobacteria, and Invertebrates. DOI 10.1007/978-1-4614-12472_2, Springer Science Business Media, LLC 2012

Kamenarska, Z.G. et al., A comparative study on the sterol composition of some brown algae from the Black Sea. Original scientific paper Institute of Organic Chemistry with Centre of Phytochemistry, Bulgarian Academy of Sciences, 
Sofia 1113, Bulgaria.

J.Serb.Chem.Soc. $\quad$ 68(4-5)269275(2003)

Koivikko, R. 2008. Brown Alga Phlorotannins Improving and Applying Chemical Methods. Department of Chemistry University of Turky Finland

Kristanti, A.V, Aminah, N.S, Tanjung, M., Kurniadi, B. 2008. Buku Ajar Fitokimia. Airlangga University Press. Surabaya

Manivannan, K., Karthikai devi, G., Anantharaman,P.,

Balasubramanian, $\mathrm{T}$.

Antimicrobial potential of selected brown seaweeds from Vedalai coastal waters, Gulf of Mannar. Asian Pacific Journal of Tropical Biomedicine (2011)114120

Marimuthu J. et al. Phytochemical characterization of brown seaweed Sargassum wightii. Asian Pacific Journal of Tropical Disease (2012)S109-S113

Moosa, M.K. Sumberdaya laut nusantara, keanekaragamanhayati laut dan pelestariannya. Loka karya Keanekaragaman Hayati Laut. Pemanfaatan secara lestari dilandasi penelitian dan penyelamatan. Widy Graha LIPI, Jakarta 23 Pebruari 1999

Putri, H.K. 2011. Pemanfaatan Rumput Laut Coklat (Sargassum sp.) sebagai Serbuk Minuman Pelangsing

Tubuh.DepartemenTeknologi

HasilPerairanFakultas

PerikananDan Ilmu Kelautan, Institut Pertanian Bogor Bogor

Reskika, A. 2011. Skripsi Evaluasi Potensi Rumput Laut Coklat (Phaeophyceae) dan Rumput Laut Hijau (Chlorophyceae) Asal Perairan Takalar Sebagai Antibakteri Vibrio spp. Jurusan Perikanan Fakultas Ilmu Kelautan dan Perikanan Universitas Hasanuddin Makassar

Rohmah W. B., Budi, S.B. dan Kartika, N.H.2001. Daya AntibakteriEkstrak Sargassum Crystaefolium dengan Berbagai Pelarut Terhadap Eschericia coli dan Vibrio haemoliticus. Malang: Fakultas Perikanan dan Ilmu KelautanUniversitas Brawijaya

Rohmah W. B., Budi, S.B. dan Kartika, N.H.2001. Daya Antibakteri Ekstrak Sargassum Crystaefolium dengan Berbagai Pelarut Terhadap Eschericia coli dan Vibrio haemoliticus. Malang: Fakultas Perikanan dan Ilmu Kelautan Universitas Brawijaya

Saleem, M., Nazir, M., Ali, M.S., Hussain, H., Lee, Y.S., Riaza, N. and Jabbara,A. Antimicrobial Natural Products: an Update on Future Antibiotic Drug Candidates. DOI: 10.1039/b916096e.

First published as an Advance Article on the web 25th November 2009

Shanmugam, S.K., Kumar, Y., Yar, K.M.S., Gupta, V. and De Clercq, E. Antimicrobial and Cytotoxic Activities of Turbinaria conoides (J.Agardh) Kuetz. Iranian Journal of Pharmaceutical Research (2010), 9 (4): 411-416

Sidharta B.R., Atmodjo, P.K. dan E. Mursyanti. Skrining Senyawa Antibakteri dari Beberapa Jenis Rumput Laut Coklat (Phaeophyceae) dari Pantai Drini, Daerah Istimewa Yogyakarta. Biota Vol. 13 (1): 1-7, Februari 2008 ISSN 0853-8670

Sudarmadji, S.B., Haryono, dan Suhardi. 2007. Analisis Bahan Makanan dan Pertanian. Yogyakarta: Liberty.

Volk.W.A dan Wheeler M.F. 1993. Mikrobiologi Dasar. Jakarta: PT. Gelora Aksara Pratama. 
ALCHEMY, Vol. 3 No. 1 Maret 2014, hal 57-66

Winarno, F.G. 2004. Kimia Bahan Pangan. Gramedia Pustaka Utama. Jakarta
Yudanto, H.A. 2001. Wilayah Perairan Indonesia. Kompas.com. diakses 21 September 2011. 